\title{
Musculoskeletal Diseases in Marfan Syndrome - A Nationwide Registry Study.
}

Niels H.Andersen ( $\nabla$ n.holmark@rn.dk)

Aalborg Universitetshospital https://orcid.org/0000-0002-5394-3016

\section{Ellen-Margrethe Hauge}

Aarhus University Hospital Skejby

Thomas Baad-Hansen

Aarhus University Hospital Skejby

Kristian A. Groth

Aalborg Hospital

Agnethe Berglund

Aarhus University Hospital Skejby

Claus H. Gravholt

Aarhus University Hospital Skejby

Kirstine Stochholm

Aarhus Universitetshospital Skejby

Research

Keywords: Inherited disease, Musculoskeletal Abnormalities, spine, pediatrics, orthopedic surgery,

Posted Date: November 19th, 2021

DOI: https://doi.org/10.21203/rs.3.rs-1076709/v1

License: (c) (1) This work is licensed under a Creative Commons Attribution 4.0 International License.

Read Full License 


\section{Abstract}

\section{Background}

Marfan syndrome is associated with abnormalities in the musculoskeletal system including scoliosis, pectus deformities, protrusio acetabuli, and foot deformities. Over a life span, many patients with Marfan syndrome will need treatment; however, the musculoskeletal morbidity over a life span is not well described. The aim of the present study was to assess the overall burden of musculoskeletal disease in patients with Marfan syndrome.

\section{Materials and Methods}

A registry-based, nationwide epidemiological study of patients with a Ghent II verified Marfan syndrome diagnosis from 1977-2014. Each patient was matched on age, and sex with up to 100 controls from the background population.

\section{Results}

We identified 407 patients with Marfan syndrome and 40,700 controls and compared their musculoskeletal diagnoses and surgical treatments using Cox proportional hazards regression (HR).

The risk of a registration of a musculoskeletal diagnosis in patients with Marfan syndrome was significantly increased compared to controls (HR: 1.94 (1.69-2.24). One out of six with Marfan syndrome was registered with scoliosis (HR: 36.7 (27.5-48.9). Scoliosis was more common in women with Marfan syndrome compared to men (HR: 4.30 (1.73-1.08)). One out of 11 were registered with a pectus deformity HR: 40.8 (28.1-59.3), and one out of three with a deformity of the foot (HR: 1.9 (1.6-2.3)). The proportion of patients with Marfan syndrome (94/407) that underwent musculoskeletal surgery was also significantly higher (HR: 1.76 (1.43-2.16)). The major areas of surgery were the spine, pectus correction, and surgery of the foot/ancle. Ten patients with Marfan syndrome had elective orthopedic surgery without being recognized and diagnosed with Marfan syndrome until later in life. None of these had scoliosis, pectus deformity or a foot deformity.

Among patients with an aortic dissection, the age at dissection was 34.3 years in those with at least one major musculoskeletal abnormality. In patients without a major abnormality the age at dissection was 45.1 years $(p<0.01)$.

\section{Conclusions}

The extend of musculoskeletal disease is quite significant in Marfan syndrome and many will need corrective surgery during their life span. Surgeons should be aware of undiagnosed patients with Marfan syndrome when treating patients with a Marfan syndrome like-phenotype.

\section{Introduction}


Marfan syndrome (MFS) is a genetic disorder with autosomal dominant heritage caused by pathological variants in the FBN1 gene [1]. The diagnosis of a patient with MFS can be based on the presence of a pathogenic variant and disease in the ascending aorta or the eye lens [2]. Since MFS is also associated with numerous abnormalities in the musculoskeletal system including scoliosis, pectus deformities, protrusio acetabuli, and foot deformities, these disorders are also featured in the systemic criteria in the Ghent II nosology and play a significant part in the diagnosis of a patient with MFS [2,3]. Beside the cardiac concerns, there is little doubt that the burdensome musculoskeletal morbidity is severely affecting persons with MFS already during childhood and adolescence $[4,5]$. The causal mechanisms behind the musculoskeletal manifestations in MFS are quite complex, but the central mechanisms are reduced production of normal fibrillin-1 and interfered formation of fibrillin microfibrils which weakens connective tissue [6]. In combination with overgrowth of the long bones both in the extremities and the ribs, the patients primarily develop deformities of the spine, chest wall and feet [7] (Figure 1). A recent study found a considerable number of musculoskeletal abnormalities in 1,575 MFS patients including scoliosis in $45 \%$, pectus deformities in $46 \%$, and pes planus in $39 \%$ [8]. Moreover, manifestations not found in the Ghent criteria, such as arachnodactyly and spondylolisthesis were also very common[8]. This huge burden of musculoskeletal disorders will affect most patients with MFS during their lifetime[9]. Many young patients will choose to have corrective surgery of the chest wall $[10,11]$ and others will need treatment of their scoliosis at some point in life [12]. The aim of the present study was to assess the overall burden of musculoskeletal disease in patients with MFS. By utilizing information from the Danish national health registries on all diagnoses and treatments related to the musculoskeletal system, we hereby describe the findings in all patients in Denmark with a Ghent-II verified diagnosis of MFS, compared to an age and sex matched background population.

\section{Methods}

We used Statistics Denmark to identify all patients in Denmark with MFS and to describe their musculoskeletal morbidity compared to a Danish control population.

Statistics Denmark is the central authority on most Danish national health care registries, including the Danish National Patient Registry [13]. The Danish registries are scientifically invaluable, as they hold information including dates and types of diagnoses on all registrations of in- and outpatients, dates and types of all surgeries, vital status, including date and cause of death and much more for all persons residing in Denmark. The health care system is tax-funded and free of charge. All data are mandatorily and automatically generated, updated, and linked via the unique personal identification number (CPRnumber) given to all persons in Denmark at birth or upon immigration. After granted permission, data can be accessed using a secured platform guaranteeing anonymity.

Previously, we identified all persons in Denmark with MFS according to the Ghent-II criteria [14]. To do so, we retrieved CPR-numbers nationwide from all persons recorded in the Danish National Patient Registry with the diagnosis Q87.4 "Marfan Syndrome" or 759.80 "Arachnodactylia (Syndroma Marfan)", according to the International Classification of diseases $10^{\text {th }}$ (ICD-10) and $8^{\text {th }}$ (ICD-8), respectively, during 1977 to 
2014. Registration of hospital and department was also retrieved. To verify the MFS diagnosis, we retrieved relevant medical records from these departments and scrutinized all records manually, as previously described [14]. In total, we identified 407 men and women with MFS who were alive in 1994 or later. We have published data on morbidity and mortality in this population $[15,16]$.

Statistics Denmark provided an age and sex matched control population, matched 1:100. All controls were alive the day their relevant MFS person was diagnosed with Marfan syndrome. For controls and for MFS, we utilized the following information: Registrations of in- and outpatient diagnoses, surgery, and for cause of death, as well as the relevant dates. For this study on the musculoskeletal morbidity, we focused on four different groups, namely rheumatic diseases, congenital deformities, dislocations, and musculoskeletal surgery. We used the ICD-10 (from 1994 to 2017) for rheumatic diseases (M001-799), for congenital deformities (Q650-689), and for dislocations (relevant codes from S030-T039). For musculoskeletal surgery: Nordic Classification of Surgical Procedures (NOMESCO) (from 1996 to 2017), primarily KN codes. All four groups were subdivided into main groups and subgroups. For the use of DMARDS we used the Anatomical Therapeutic Chemical code (ATC) and the treatment procedure code as described previously [17]. The validity of some rheumatic diagnoses in the Danish registries have been investigated earlier, with positive predictive findings of approximately $88 \%$ for rheumatoid arthritis [18] .

To describe the relation between musculoskeletal disease and the age at aortic dissection, we divided the MFS patients in two groups, one where all had at least one registration of a musculoskeletal abnormality from the Ghent II classification (scoliosis, pes planus, or pectus abnormalities), and one where none had such a musculoskeletal registration. Previously, we identified all with MFS, who had an ICD-8 or 10 registration with an aortic dissection, corresponding to 80 persons [19].

\section{Statistics}

Basic epidemiological data are given using medians and interquartile ranges (IQR).

For all four groups, time to first registration combined and in all main groups were analyzed using stratified Cox regression, where each patient with MFS and his or her matched control constituted one stratum. For all analyses, time at risk started at birth of the patient with MFS or at start of registry, whichever came last, and ended at the date of relevant registration, date of death, end of study, or emigration, whichever came first. When comparing women with MFS with men with MFS, year of birth was used as a co-variate.

Age at aortic event was log-transferred and the t-test applied when comparing those with and without a musculoskeletal registration from the Ghent II classification.

Stata 16.1 for Windows (StataCorp LP, College Station, TX, USA) was used for all calculations.

\section{Ethics}


The study was approved by the Scientific Ethical Committee (31422) and the Danish Data Protection Agency (2011-41-6986). The European Union's General Data Protection Regulation does not accept any possibility of personal identification of cases; thus, Statistics Denmark prohibits specification of the exact number of cases with a given condition if less than four, and we therefore must report these as " $<4$ ".

Availability of data and materials

The datasets analyzed during the current study are available from the corresponding author on reasonable request.

\section{Results}

We identified 407 persons with MFS (194 women) and retrieved 40,700 controls (19,400 women) from the background population. At the end of 2017, 349 patients with MFS were alive and living in Denmark with a median age of 38 years (Table 1 ). The follow-up period covered 16,439 person years from birth to the end of the observation period.

Table 1

Epidemiological data from the Marfan syndrome cohort and the background population

\begin{tabular}{|llllll|}
\hline & Number & $\begin{array}{l}\text { Year of birth } \\
\text { (IQR) }\end{array}$ & $\begin{array}{l}\text { Age (years)* } \\
(\text { IQR })\end{array}$ & $\begin{array}{l}\text { Years } \\
\text { at risk }\end{array}$ & $\begin{array}{l}\text { Number of } \\
\text { deaths }\end{array}$ \\
\hline Females with MFS & 194 & $1976(1961-1992)$ & $39(23-54)$ & 7954 & 31 \\
\hline Males with MFS & 213 & $1978(1963-1994)$ & $37.5(21-50)$ & 8107 & 27 \\
\hline Control, females & 19,400 & $1976(1961-1992)$ & $40(25-55)$ & - & 1125 \\
\hline Control, males & 21,300 & $1978(1963-1994)$ & $39(22-52)$ & - & 878 \\
\hline
\end{tabular}

The burden of musculoskeletal disorders was quite significant, with an almost doubled risk (HR: 1.94 (1.69-2.24) of a registration of a musculoskeletal diagnosis (Figure 2).

Moreover, the proportion of patients with MFS that underwent musculoskeletal surgery was also significantly increased (HR: 1.76 (1.43-2.16)). (Figure 3).

\section{Scoliosis and spinal surgery}

More than one out of six (69/407) with MFS were registered with an ICD-10 diagnosis of scoliosis, corresponding to a HR of 37 (Table 3). Significantly more women with MFS were affected compared to men (Table 2). Furthermore, 3\% (14/407) with MFS were registered with having corrective spinal surgery due to scoliosis and additionally 17 patients with MFS were registered with corrective neck or spinal surgery (Table 3). The median age at the time of scoliosis surgery was 10 years for MFS and 20 years for the controls. The median number of registrations of scoliosis surgery was 2 (IQR 1-4) in MFS and 1 (IQR 
1-1) in controls, (Kruskal Wallis test: $p<0.01$ ). No patients with MFS were registered with complications such as infections in tendons, joints, discs, and bones, corresponding to the code NOMESCO "KNAS", whereas six of the controls had such a registration. Dislocations of the spine were limited in MFS compared to controls (Table 4). 
Table 2

Spinal and rheumatic disease in Marfan syndrome

\begin{tabular}{|c|c|c|c|c|}
\hline Diagnoses & $\begin{array}{l}\text { ICD-10 } \\
\text { codes }\end{array}$ & $\begin{array}{l}\text { Number of } \\
\text { MFS vs } \\
\text { controls }\end{array}$ & $\begin{array}{l}\mathrm{HR}(95 \% \\
\mathrm{Cl})\end{array}$ & $\begin{array}{l}\text { HR }(95 \% \mathrm{Cl}) \text { MFS only, } \\
\text { females vs males* }\end{array}$ \\
\hline Combinedt & $\begin{array}{l}\text { M001- } \\
799\end{array}$ & $207 / 13,367$ & $\begin{array}{l}1.94 \\
(1.69- \\
2.24)\end{array}$ & $1.36(1.03-1.80)$ \\
\hline \multicolumn{5}{|l|}{ Kyphosis, lordosis, and scoliosis } \\
\hline Kyphosis and lordosis & $\begin{array}{l}\text { M400- } \\
405\end{array}$ & $6 / 25$ & $\begin{array}{l}23.8 \\
(9.8- \\
58.1)\end{array}$ & $0.52(0.10-2.87)$ \\
\hline Scoliosis, including & $\begin{array}{l}\text { M410- } \\
419\end{array}$ & $68 / 216$ & $\begin{array}{l}36.7 \\
(27.5- \\
48.9)\end{array}$ & $2.72(1.60-4.63)$ \\
\hline Scoliosis in the young & $\begin{array}{l}\text { M410- } \\
\text { M411 }\end{array}$ & $27 / 102$ & $\begin{array}{l}31.2 \\
(20.0- \\
48.1)\end{array}$ & $4.30(1.73-1.08)$ \\
\hline \multicolumn{5}{|l|}{ Inflammatory arthritis } \\
\hline Reactive arthritis & M02-03 & N/A & & \\
\hline Inflammatory polyarthritis & M05-14 & $12 / 752$ & $\begin{array}{l}1.71 \\
(0.97- \\
3.03)\end{array}$ & $0.51(0.15-1.73)$ \\
\hline Inflammatory spondylopathies & M45-46 & $\mathrm{N} / \mathrm{A}$ & & \\
\hline \multicolumn{5}{|l|}{$\begin{array}{l}\text { Degenerative and other } \\
\text { musculoskeletal disorders }\end{array}$} \\
\hline Osteoarthritis & M15-19 & $23 / 2,052$ & $\begin{array}{l}1.12 \\
(0.73- \\
1.72)\end{array}$ & $1.50(0.61-3.68)$ \\
\hline $\begin{array}{l}\text { Other joint disorders, including } \\
\text { arthralgia }\end{array}$ & M20-25 & $78 / 4,520$ & $\begin{array}{l}1.93 \\
(1.55- \\
2.42)\end{array}$ & $1.21(0.77-1.90)$ \\
\hline $\begin{array}{l}\text { Spondylosis and other } \\
\text { spondylopathies }\end{array}$ & M47-49 & $7 / 645$ & $\begin{array}{l}1.16 \\
(0.55- \\
2.45)\end{array}$ & $6.39(0.76-54.1)$ \\
\hline Intervertebral disc disorders & M50-51 & $7 / 1,559$ & $\begin{array}{l}0.47 \\
(0.22- \\
0.98)\end{array}$ & $1.32(0.29-5.99)$ \\
\hline Dorsalgia & M53-54 & $37 / 2.301$ & $\begin{array}{l}1.76 \\
(1.26- \\
2.43)\end{array}$ & $1.44(0.75-2.76)$ \\
\hline
\end{tabular}




\begin{tabular}{|c|c|c|c|c|}
\hline Diagnoses & $\begin{array}{l}\text { ICD-10 } \\
\text { codes }\end{array}$ & $\begin{array}{l}\text { Number of } \\
\text { MFS vs } \\
\text { controls }\end{array}$ & $\begin{array}{l}\mathrm{HR}(95 \% \\
\mathrm{Cl})\end{array}$ & $\begin{array}{l}\text { HR }(95 \% \mathrm{Cl}) \text { MFS only, } \\
\text { females vs males* }\end{array}$ \\
\hline \multicolumn{5}{|l|}{ Soft tissue disorders } \\
\hline $\begin{array}{l}\text { Disorders of synovium and } \\
\text { tendons }\end{array}$ & $\begin{array}{l}\text { M650- } \\
689\end{array}$ & $18 / 1,686$ & $\begin{array}{l}1.12 \\
(0.71- \\
1.79)\end{array}$ & $2.20(0.82-5.88)$ \\
\hline Other soft tissue disorders & $\begin{array}{l}\text { M700- } \\
790\end{array}$ & $38 / 3,504$ & $\begin{array}{l}1.14 \\
(0.83- \\
1.57)\end{array}$ & $1.50(0.78-2.89)$ \\
\hline
\end{tabular}


Table 3

Registrations of musculoskeletal surgery in Marfan syndrome

\begin{tabular}{|c|c|c|c|c|}
\hline Surgery & NOMESCO & $\begin{array}{l}\text { Number of } \\
\text { MFS/controls }\end{array}$ & $\begin{array}{l}\text { HR } \\
\text { MFS vs } \\
\text { controls } \\
(95 \% \\
\text { Cl) }\end{array}$ & $\begin{array}{l}\text { HR MFS } \\
\text { only, } \\
\text { women } \\
\text { vs men * } \\
(95 \% \mathrm{Cl})\end{array}$ \\
\hline Combined $t$ & $\mathrm{KN}$ & $94 / 5,949$ & $\begin{array}{l}1.76 \\
(1.43- \\
2.16)\end{array}$ & $\begin{array}{l}0.90 \\
(0.60- \\
1.35)\end{array}$ \\
\hline \multicolumn{5}{|l|}{ Surgery of the spine } \\
\hline Spine and neck & KNA & $17 / 248$ & $\begin{array}{l}7.5(4.6- \\
12.3)\end{array}$ & $\begin{array}{l}2.06 \\
(0.76- \\
5.58)\end{array}$ \\
\hline Scoliosis & $\begin{array}{l}\text { KNAG71- } \\
75 \\
\text { KNAT21- } \\
25\end{array}$ & $14 / 87$ & $\begin{array}{l}17.6 \\
(10.0- \\
31.1)\end{array}$ & $\begin{array}{l}2.71 \\
(0.85- \\
8.67)\end{array}$ \\
\hline \multicolumn{5}{|l|}{ Surgery of the chest wall } \\
\hline Correction pectus carinatum & KGAF00 & $6 /<4$ & $>200$ & N/A \\
\hline Correction pectus excavatum & KGAF03 & $7 / 9$ & $\begin{array}{l}77.5 \\
(28.9- \\
208.1)\end{array}$ & N/A \\
\hline \multicolumn{5}{|l|}{ Upper extremity surgery } \\
\hline Shoulder and upper arm & KNB & $8 / 788$ & $\begin{array}{l}1.07 \\
(0.53- \\
2.15)\end{array}$ & $\begin{array}{l}0.87 \\
(0.21- \\
3.60)\end{array}$ \\
\hline Elbow and forearm & $\mathrm{KNC}$ & $14 / 862$ & $\begin{array}{l}1.68 \\
(0.99- \\
2.85)\end{array}$ & $\begin{array}{l}0.28 \\
(0.08- \\
1.05)\end{array}$ \\
\hline Wrist and hand & KND & $12 / 1,314$ & $\begin{array}{l}0.95 \\
(0.54- \\
1.68)\end{array}$ & $\begin{array}{l}1.01 \\
(0.32- \\
3.18)\end{array}$ \\
\hline \multicolumn{5}{|c|}{ Pelvic and lower extremity surgery } \\
\hline Pelvis & KNE & $<4 / 63$ & N/A & N/A \\
\hline Hip joint and thigh & KNF & $17 / 617$ & $\begin{array}{l}2.95 \\
(1.82- \\
4.78)\end{array}$ & $\begin{array}{l}1.11 \\
(0.42- \\
2.88)\end{array}$ \\
\hline
\end{tabular}




\begin{tabular}{|c|c|c|c|c|}
\hline Surgery & NOMESCO & $\begin{array}{l}\text { Number of } \\
\text { MFS/controls }\end{array}$ & $\begin{array}{l}\text { HR } \\
\text { MFS vs } \\
\text { controls } \\
(95 \% \\
\text { Cl) }\end{array}$ & $\begin{array}{l}\text { HR MFS } \\
\text { only, } \\
\text { women } \\
\text { vs men * } \\
(95 \% \mathrm{Cl})\end{array}$ \\
\hline Hip arthroplasty & KNFB & $4 / 222$ & $\begin{array}{l}1.89 \\
(0.70- \\
5.10)\end{array}$ & $\begin{array}{l}1.05 \\
(0.15- \\
7.51)\end{array}$ \\
\hline Knee and lower leg & KNG & $25 / 2,289$ & $\begin{array}{l}1.13 \\
(0.76- \\
1.68)\end{array}$ & $\begin{array}{l}0.69 \\
(0.31- \\
1.54)\end{array}$ \\
\hline Ankle and foot & $\mathrm{KNH}$ & $28 / 996$ & $\begin{array}{l}3.08 \\
(2.12- \\
4.49)\end{array}$ & $\begin{array}{l}1.40 \\
(0.66- \\
2.96)\end{array}$ \\
\hline $\begin{array}{l}\text { Resection of joint, arthroplasty and } \\
\text { arthrodesis in ankle and foot }\end{array}$ & KNHG & $14 / 88$ & $\begin{array}{l}16.9 \\
(9.6- \\
29.8)\end{array}$ & $\begin{array}{l}0.97 \\
(0.34- \\
2.789)\end{array}$ \\
\hline Osteotomi of ankle or foot & $\begin{array}{l}\text { KNHK50- } \\
69\end{array}$ & $7 / 151$ & $\begin{array}{l}4.80 \\
(2.25- \\
10.24)\end{array}$ & $\begin{array}{l}1.48 \\
(0.33- \\
6.62)\end{array}$ \\
\hline Myotomi or tenotomy of ankle or foot & KNHL39 & $6 / 41$ & $\begin{array}{l}17.3 \\
(7.3- \\
41.4)\end{array}$ & $\begin{array}{l}2.17 \\
(0.39- \\
12.0)\end{array}$ \\
\hline $\begin{array}{l}\text { Correction of deformity of ankle or foot using } \\
\text { external or internal fixation }\end{array}$ & KNHT49 & $<4 / 13$ & $\begin{array}{l}17.7 \\
(3.9- \\
79.7)\end{array}$ & N/A \\
\hline $\begin{array}{l}\text { Removal of internal fixation device from } \\
\text { ankle or foot }\end{array}$ & KNHU49 & $14 / 178$ & $\begin{array}{l}8.3(4.8- \\
14.4)\end{array}$ & $\begin{array}{l}1.41 \\
(0.49- \\
4.08)\end{array}$ \\
\hline
\end{tabular}


Table 4

Dislocations of the joints in Marfan syndrome

\begin{tabular}{|c|c|c|c|c|}
\hline Diagnoses & $\begin{array}{l}\text { ICD-10 } \\
\text { codes }\end{array}$ & $\begin{array}{l}\text { Number of } \\
\text { MFS vs } \\
\text { controls }\end{array}$ & $\mathrm{HR}(95 \% \mathrm{Cl})$ & $\begin{array}{l}\text { HR }(95 \% \mathrm{Cl}) \text { MFS only, women } \\
\text { vs men* }\end{array}$ \\
\hline Combined & All below & $149 / 13617$ & $\begin{array}{l}1.17(1.00- \\
1.38)\end{array}$ & $0.69(0.50-0.96)$ \\
\hline Jaw dislocation & $\begin{array}{l}\text { S030- } \\
\text { S035 }\end{array}$ & $11 / 1574$ & $\begin{array}{l}0.72(0.40- \\
1.29)\end{array}$ & $0.98(0.30-3.23)$ \\
\hline Cervical dislocation & $\begin{array}{l}\text { S130- } \\
\text { S136 }\end{array}$ & $7 / 1307$ & $\begin{array}{l}0.54(0.26- \\
1.15)\end{array}$ & $0.85(0.19-3.80)$ \\
\hline Shoulder dislocation & $\begin{array}{l}\text { S430- } \\
\text { S437 }\end{array}$ & $11 / 968$ & $\begin{array}{l}1.22(0.68- \\
2.22)\end{array}$ & $0.51(014-1.75)$ \\
\hline Elbow dislocation & $\begin{array}{l}\text { S530- } \\
\text { S534 }\end{array}$ & $7 / 638$ & $\begin{array}{l}1.12(0.53- \\
2.36)\end{array}$ & $0.20(0.02-1.70)$ \\
\hline Finger dislocation & $\begin{array}{l}\text { S630- } \\
\text { S637 }\end{array}$ & 41/3999 & $\begin{array}{l}1.07(0.79- \\
1.46)\end{array}$ & $0.54(0.28-1.04)$ \\
\hline Hip dislocation & $\begin{array}{l}\text { S730- } \\
\text { S731 }\end{array}$ & $<4 / 96$ & $\mathrm{~N} / \mathrm{A}$ & $\mathrm{N} / \mathrm{A}$ \\
\hline $\begin{array}{l}\text { Dislocations, } \\
\text { knee/patella }\end{array}$ & $\begin{array}{l}\text { S830- } \\
\text { S837 }\end{array}$ & $40 / 3724$ & $\begin{array}{l}1.13(0.83- \\
1.55)\end{array}$ & $0.75(0.40-1.40)$ \\
\hline $\begin{array}{l}\text { Dislocations, } \\
\text { ankle/foot }\end{array}$ & $\begin{array}{l}\text { S930- } \\
\text { S936 }\end{array}$ & $77 / 7130$ & $\begin{array}{l}1.13(0.90- \\
1.42)\end{array}$ & $0.96(0.61-1.50)$ \\
\hline $\begin{array}{l}\text { More than one } \\
\text { dislocation }\end{array}$ & $\begin{array}{l}\text { T030- } \\
\text { T039 }\end{array}$ & $<4 / 17$ & $\mathrm{~N} / \mathrm{A}$ & $\mathrm{N} / \mathrm{A}$ \\
\hline
\end{tabular}

\section{Chest wall deformities}

Deformity of the chest wall was the most common congenital skeletal deformity. One out of $11(37 / 407)$ with MFS were registered with either pectus excavatum (HR: 49.8 (28.7-59.3)) or pectus carinatum (HR: 139.8 (72.1-271.1)) and 13/37 had pectus surgery (Table 3). None were registered with aortic surgery after pectus surgery. The median age at pectus surgery was 17 years for MFS and 16 years for the controls. There was no difference between men and women with MFS.

\section{Disease in lower extremities and feet}

Registration of congenital malformations of the hip was not significantly more common in MFS (HR:2.54 (0.94-6.85). However, the diagnosis of protrusion acetabuli was almost not used in the register, and significantly more patients with Marfan syndrome indeed had surgery of the hip (HR: 2.95 (1.82-4.78)) (Table 3). Almost one out of three with MFS (130/407) had a registration with either pes planus (HR:26.0 (15.2-44.3), congenital deformity of the foot HR: 15.6 (11.0-22.1), or congenital valgus deformities in foot 
HR: 8.4 (3.9-18.2), whereas this applied to less than one out of five controls $(7809 / 40,700)$ resulting in a HR of $1.9(1.6-2.3)$.

\section{Rheumatic Disease}

At the age of 25 years, $63 \%$ of persons with MFS and $24 \%$ of the controls had at least one registration with a rheumatic diagnosis. The risk of being registered with any rheumatic disorder was almost doubled (HR:1.9 (1.7-2.2)) in MFS compared to controls, with a significantly increased risk in women compared to men (Table 2). Most rheumatic diagnoses were related to low back pain or joint pain (Table 2). Inflammatory rheumatic disorders were not more common in patients with MFS, and none was treated with a DMARD.

\section{Non-spinal orthopedic surgery}

The combined risk of being registered with non-spinal orthopedic surgery (here defined as NOMESCO code KN) was significantly increased in MFS compared to controls (HR: 1.57 (1.27-1.95)) (Table 3), and this applied to three out of eight main groups. At the age of 25 years, $28 \%$ of persons with MFS and $12 \%$ of the controls had at least one registration with orthopedic surgery. Women and men with MFS were equally affected (Figure 3). The major surgical areas were hip surgery and surgery of the ankle and foot (Table 4).

\section{Dislocations}

The registration of any dislocation was seen with a borderline increased HR of $1.17(1.00-1.39, p=0.055)$ in MFS. Congenital dislocations of the hip were quite rare (Table 4). In MFS, the risk of being registered with a dislocation was significantly lower in women compared to men (Table 4).

\section{Cancer}

None in the MFS cohort were registered with cancer of the bone or connective tissue.

\section{Medication}

None in the MFS cohort were registered with the use of DMARDS, or in- hospital or out-patient clinic glucocorticoid injections.

\section{Surgery according to phenotype}

Presence of at least one of the major musculoskeletal phenotypes (scoliosis, pectus deformities, and pes planus) was registered as a diagnosis in 102/407 (25.1\%) of patients with MFS and in 544/40700 (1.4\%) of controls. Interestingly, ten patients underwent corrective surgery without being recognized and diagnosed with MFS until later in life. However, none one of these patients were registered with phenotypical characteristics associated to MFS. 


\section{Aortic dissection and musculoskeletal phenotype}

Eighty patients with MFS had an aortic dissection, and 102 had at least one musculoskeletal registration from the Ghent II classification. Among the patients with MFS and an aortic dissection, those with at least one musculoskeletal Ghent II registration, had an age at dissection of 34.3 years, whereas age at dissection in those without a musculoskeletal Ghent II registration was 45.1 years $(p<0.01)$.

\section{Discussion}

The main finding of the present study was an extensive burden of musculoskeletal diseases in patients with Marfan syndrome, primarily related to the spine and chest wall. At the age of sixty years, more than half of the population with MFS had been diagnosed with a musculoskeletal disorder and many needed surgical treatment. In addition, it seemed that patients with a more abnormal musculoskeletal phenotype developed aortic dissection at an earlier age than patients with a phenotype without obvious musculoskeletal disease.

A national registry-based study uses automatically collected data that reflect clinical practice and registered events related to an entire population. This means that the presented data reflect outpatient visits, admissions, or surgical procedures and not issues assessed in a research setting. So, if the patient does not choose to see a physician due to a musculoskeletal problem she or he will not be registered in the present dataset. Moreover, minor abnormalities in the spine or chest wall may not have been registered if they were considered mild or were without symptoms.

In general terms, the musculoskeletal problems in MFS are caused by a ligamentous laxity and excessive longitudinal growth of the tubular bones $[3,5,20]$. This has effect on the weightbearing joints and on the spine where scoliosis is a common feature in the MFS phenotype [21].

Compared to the background population, a relatively high number of patients with MFS had spinal surgery and it was performed at significantly younger age and mostly in women. These findings are in accordance with other observational studies $[12,21]$. Scoliosis bracing for children and adolescents can be effective but growth-friendly spinal surgery may be necessary in many cases which includes staged surgery and growth friendly spine implants $[22,23]$. Both the increased risk of implant failure in these cases and the need for multiple surgical stages is reflected in our findings where the number of surgical procedures was twice as high as in the background population [21,22]. However, we did not see a significantly higher number of surgical complications among patients with MFS, as previously reported [23]. Spine surgery in patients with MFS has changed over the years with a decline in the number of procedures and a trend towards a posterior surgical approach $[12,23]$. In Denmark, the caretaking of patients with MFS is centralized to two hospitals, which ensures the highest experience among surgeons engaging in this rare condition. Specialized rehabilitation of these patients must also be a key issue to ensure the best possible result [24]. 
Westphal et al. reported a pectus carinatum prevalence of $0.7 \%$ and a prevalence of pectus excavatum $1.3 \%$ in a cohort of 1332 normal children aged 11-14 years [25]. Among patients with MFS, we found a much higher number of patients with chest wall deformities (around 10 percent) and one in four cases chose to have corrective surgery. Surgical correction of chest wall deformities with the NUSS-procedure began in 2001 in Denmark and during the first 15 years over 1700 patients underwent this minimal invasive procedure [26]. With the NUSS-procedure, a metal bar reaching from one midaxillary line to the other is inserted beneath the sternum with a minimal invasive surgical technique [27]. Considering the low incidence of chest deformities reported in the literature and an annual number of births in Denmark of around 50,000, the number of NUSS-procedures is relatively high and could indicate that a large pool of patients have been offered surgery during the first years after introducing the NUSS-procedure in Denmark [25, 26, 28]. Naturally, this new interest will also have included patients with MFS, which can have increased the incidence of NUSS-procedures during the follow-up period of the present study [11]. After the NUSS-procedure, the metal bar has to remain in this position for approximately three years which hinders quick access to the aorta in case of an aortic dissection [11]. It is therefore important to ensure the correct timing of corrective chest surgery in patients with MFS or to combine open heart and chest surgery in one procedure [29]. We did not find any cases with a need for aortic surgery after a NUSSprocedure, which indicates that these patients were young and well selected.

Protrusio acetabuli is an intrapelvic displacement of the acetabulum and femoral head and is found in more than $75 \%$ of patients with MFS $[30,31]$. Even though it is a feature in the Ghent II nosology it is not necessary to diagnose if the phenotype is otherwise obvious [2]. This is probably the reason why the prevalence was very low in this cohort. Protrusio acetabuli can lead to hip dysfunction and impingement that may need surgical treatment [31,32]. Over time, protrusio acetabuli can also cause osteoarthritis and a need for hip replacement [31, 32]. Accordingly, there was a significantly increased number of hip surgeries in our population. However, the number of hip arthroplasties was not higher than in the background population. This clearly shows that hip problems are quite common in MFS. With an increasing life span of the patient with MFS there will be more patients with a need for hip replacement in their senior years $[15,31]$.

Flatfoot and hindfoot deformities are also common in MFS [4]. The growth of the metatarsals and phalanges and the ligament laxity in the foot causes loss of the medial arch [33]. The primary treatment is non-surgical with shoe orthoses and physical therapy exercises [34]. However, surgery may be necessary to relieve pain [9]. There is not much literature regarding surgical techniques and no consensus on how to approach this problem with surgery $[34,35]$. This contrasts with our findings, where we saw a very high number of surgical foot and ancle treatments including arthroplasty and arthrodesis. This surgical practice in Denmark most likely reflect the magnitude of feet problems in MFS but is not supported by a recommendation that surgery should be preferred in patients with MFS [34].

Ligament laxity should lead to joint dislocations. However, this was not the case in this cohort. Patients with MFS did not have significantly more joint dislocations in the fingers, shoulders or in the lower extremities (i.e., patella luxations). Patients with MFS may have more sedentary lifestyle where they 
refrain from sports, either due to pain and disabilities or concerns about aortic dissection $[9,36]$. This will obviously minimize the number of traumatic dislocations and is probably why the number of dislocations was low.

Some inherited disorders may be mistaken as a rheumatic disease and the starting point of treatment will therefore be at a rheumatologist [37]. In the present study, patients with MFS were mainly seen by a rheumatologist due to musculoskeletal pain, which is a major issue in MFS $[9,38]$. From a previous study in this population, we have shown that more than one in four patients use analgesics (including opioids) on a regular basis [38]. We did not find an increased prevalence of inflammatory rheumatic disorders compared to the background population.

The finding of ten patients with MFS who underwent corrective surgery due to a musculoskeletal disorder without being diagnosed is quite remarkable. This result should be a reminder to all surgeons and rheumatologist in pediatric or adult care, to be aware of patients with abnormal phenotypes that could have MFS $[4,8,39]$. For these patients it could be lifesaving to get the diagnosis right, especially since patients with a more profound musculoskeletal phenotype experienced aortic dissection ten years earlier than patients without obvious phenotypical features [19, 40].

\section{Limitations}

A register study has several limitations and only provides data on what is found and registered by doctors. A nationwide set-up stretched over many years is never as accurate as a single center cohort where the patients are taken care of by specialists. We also do not have the patients' genotypes. We cannot exclude that some patients in Denmark are not yet diagnosed or have already died without being diagnosed correctly. It is also likely that we primarily included case patients with an obvious phenotype and there may also be an under-registration of some types of minor issues like minor abnormalities of the chest and spinal column.

\section{Conclusion}

The extend of musculoskeletal disease is quite significant in Marfan syndrome and many will need corrective surgery during their life span. Surgeons should be aware of undiagnosed patient with Marfan syndrome when treating patients with a Marfan syndrome like phenotype.

\section{Declarations}

\section{Authors' contributions}

Drs Andersen, Groth, Gravholt, and Stochholm conceptualized and designed the study, designed the data collection, collected data, and carried out all analysis and calculations, drafted the initial manuscript and reviewed and revised the manuscript. 
Authors Hauge, Baad-Hansen, and Berglund supervised data collection, contributed to the design of the study and critically reviewed the manuscript.

All authors commented critically on the manuscript and approved the final manuscript as submitted and agree to be accountable for all aspects of the work.

\section{Funding}

The project was done with no specific support

\section{Competing interests}

The authors have no financial and non-financial competing interests to disclose.

\section{References}

1. Dietz HC, Cutting GR, Pyeritz RE, Maslen CL, Sakai LY, Corson GM, et al. Marfan syndrome caused by a recurrent de novo missense mutation in the fibrillin gene. Nature. 1991;352:337-9.

2. Loeys BL, Dietz HC, Braverman AC, Callewaert BL, De Backer J, Devereux RB, et al. The revised Ghent nosology for the Marfan syndrome. J Med Genet. 2010;47:476-85.

3. Shirley ED, Sponseller PD. Marfan syndrome. J Am Acad Orthop Surg.2009;17:572-81.

4. De Maio F, Fichera A, De Luna V, Mancini F, Caterini R. Orthopaedic Aspects of Marfan Syndrome: The Experience of a Referral Center for Diagnosis of Rare Diseases. Adv Orthop. 2016;2016:8275391.

5. Vanem TT, Böker T, Sandvik GF, Kirkhus E, Smith H-J, Andersen K, et al. Marfan syndrome: Evolving organ manifestations-A 10-year follow-up study. Am J Med Genet A. 2020;182:397-408.

6. Thomson J, Singh M, Eckersley A, Cain SA, Sherratt MJ, Baldock C. Fibrillin microfibrils and elastic fibre proteins: Functional interactions and extracellular regulation of growth factors. Semin Cell Dev Biol. 2019;89:109-17.

7. De Maio F, Pisano C, Caterini A, Efremov K, Ruvolo G, Farsetti P. Orthopaedic aspects in seventy-two children affected by Marfan syndrome. Correlations between pathological features and fibrillin-1 gene mutations. J Biol Regul Homeost Agents. 2020;34:69-73.

8. Arnaud P, Milleron O, Hanna N, Ropers J, Ould Ouali N, Affoune A, et al. Clinical relevance of genotypephenotype correlations beyond vascular events in a cohort study of 1500 Marfan syndrome patients with FBN1 pathogenic variants. Genet Med Off J Am Coll Med Genet. 2021;23:1296-304.

9. Speed TJ, Mathur VA, Hand M, Christensen B, Sponseller PD, Williams KA, et al. Characterization of pain, disability, and psychological burden in Marfan syndrome. Am J Med Genet A. 2017;173:315-23. 
10. Lomholt JJ, Jacobsen EB, Thastum M, Pilegaard H. A prospective study on quality of life in youths after pectus excavatum correction. Ann Cardiothorac Surg. 2016;5:456-65.

11. Kelly RE, Goretsky MJ, Obermeyer R, Kuhn MA, Redlinger R, Haney TS, et al. Twenty-one years of experience with minimally invasive repair of pectus excavatum by the Nuss procedure in 1215 patients. Ann Surg. 2010;252:1072-81.

12. Chung AS, Renfree S, Lockwood DB, Karlen J, Belthur M. Syndromic Scoliosis: National Trends in Surgical Management and Inpatient Hospital Outcomes: A 12-Year Analysis. Spine. 2019;44:1564-70.

13. Schmidt M, Schmidt SAJ, Sandegaard JL, Ehrenstein V, Pedersen L, Sørensen HT. The Danish National Patient Registry: a review of content, data quality, and research potential. Clin Epidemiol. 2015;7:449-90.

14. Groth KA, Hove H, Kyhl K, Folkestad L, Gaustadnes M, Vejlstrup N, et al. Prevalence, incidence, and age at diagnosis in Marfan Syndrome. Orphanet J Rare Dis. 2015;10:153.

15. Groth KA, Stochholm K, Hove H, Andersen NH, Gravholt CH. Causes of Mortality in the Marfan Syndrome (from a Nationwide Register Study). Am J Cardiol. 2018;122:1231-5.

16. Andersen NH, Groth KA, Berglund A, Hove H, Gravholt CH, Stochholm K. Non-aortic cardiovascular disease in Marfan syndrome: a nationwide epidemiological study. Clin Res Cardiol Off J Ger Card Soc. 2021;110:1106-15.

17. Tinggaard AB, de Thurah A, Andersen IT, Riis AH, Therkildsen J, Winther S, et al. Rheumatoid Arthritis as a Risk Factor for Coronary Artery Calcification and Obstructive Coronary Artery Disease in Patients with Chest Pain: A Registry Based Cross-Sectional Study. Clin Epidemiol. 2020;12:679-89.

18. Linauskas A, Overvad K, Johansen MB, Stengaard-Pedersen K, de Thurah A. Positive predictive value of first-time rheumatoid arthritis diagnoses and their serological subtypes in the Danish National Patient Registry. Clin Epidemiol. 2018;10:1709-20.

19. Groth KA, Stochholm K, Hove H, Kyhl K, Gregersen PA, Vejlstrup N, et al. Aortic events in a nationwide Marfan syndrome cohort. Clin Res Cardiol Off J Ger Card Soc. 2017;106:105-12.

20. Milewicz DM, Braverman AC, De Backer J, Morris SA, Boileau C, Maumenee IH, et al. Marfan syndrome. Nat Rev Dis Primer. 2021;7:64.

21. Kurucan E, Bernstein DN, Ying M, Li Y, Menga EN, Sponseller PD, et al. Trends in spinal deformity surgery in Marfan syndrome. Spine J Off J North Am Spine Soc. 2019;19:1934-40.

22. Bellaire LL, Zhang C, Smith JT, Heflin JA, Klatt J, Roye D, et al. Growth-friendly Spinal Instrumentation in Marfan Syndrome Achieves Sustained Gains in Thoracic Height Amidst High Rates of Implant Failure. J Pediatr Orthop. 2021;41:e204-10. 
23. Zenner J, Hitzl W, Meier O, Auffarth A, Koller H. Surgical outcomes of scoliosis surgery in Marfan syndrome. J Spinal Disord Tech. 2014;27:48-58.

24. Benninghoven D, Hamann D, von Kodolitsch Y, Rybczynski M, Lechinger J, Schroeder F, et al. Inpatient rehabilitation for adult patients with Marfan syndrome: an observational pilot study. Orphanet J Rare Dis. 2017;12:127.

25. Westphal FL, Lima LC de, Lima Neto JC, Chaves AR, Santos Júnior VL dos, Ferreira BLC. Prevalence of pectus carinatum and pectus excavatum in students in the city of Manaus, Brazil. J Bras Pneumol Publicacao Of Soc Bras Pneumol E Tisilogia. 2009;35:221-6.

26. Pilegaard HK. Single centre experience on short bar technique for pectus excavatum. Ann Cardiothorac Surg. 2016;5:450-5.

27. Nuss D, Kelly REJ, Croitoru DP, Katz ME. A 10-year review of a minimally invasive technique for the correction of pectus excavatum. J Pediatr Surg. 1998;33:545-52.

28. Kolte AM, Westergaard D, Lidegaard $\varnothing$, Brunak S, Nielsen HS. Chance of live birth: a nationwide, registry-based cohort study. Hum Reprod Oxf Engl. 2021;36:1065-73.

29. Media AS, Pilegaard HK, de Paoli FV. Combining Correction of Pectus Excavatum and Open Heart Surgery in a Single-Stage Procedure. Ann Thorac Surg. 2020;109:e71-4.

30. Chun KJ, Yang JH, Jang SY, Lee SH, Gwag HB, Chung T-Y, et al. Analysis of Protrusio Acetabuli Using a CT-based Diagnostic Method in Korean Patients with Marfan Syndrome: Prevalence and Association with Other Manifestations. J Korean Med Sci. 2015;30:1260-5.

31. Thakkar SC, Foran JRH, Mears SC, Sponseller PD. Protrusio acetabuli and total hip arthroplasty in patients with Marfan syndrome. J Arthroplasty. 2012;27:776-82.

32. Hanke MS, Steppacher SD, Zurmühle CA, Siebenrock KA, Tannast M. Hips with Protrusio Acetabuli Are at Increased Risk for Failure After Femoroacetabular Impingement Surgery: A 10-year Followup. Clin Orthop. 2016;474:2168-80.

33. Lindsey JM, Michelson JD, MacWilliams BA, Sponseller PD, Miller NH. The foot in Marfan syndrome: clinical findings and weight-distribution patterns. J Pediatr Orthop. 1998;18:755-9.

34. Bitterman AD, Sponseller PD. Marfan Syndrome: A Clinical Update. J Am Acad Orthop Surg. 2017;25:603-9.

35. Ohashi S, Ikoma K, Kido M, Oka Y, Kim W-C, Kubo T. Two-stage correction using the Taylor Spatial Frame for severe hindfoot deformity in a patient with Marfan syndrome: A case report. J Orthop Sci Off J Jpn Orthop Assoc. 2019;24:178-83. 
36. Velvin G, Johansen H, Vardeberg K, Sjögren Fugl-Meyer K, Wilhelmsen J-E, Lidal I. Physical exercise for people with hereditable thoracic aortic disease. A study of patient perspectives. Disabil Rehabil. 2021;43:2464-71.

37. Kaya Akca U, Simsek Kiper PO, Urel Demir G, Sag E, Atalay E, Utine GE, et al. Genetic disorders with symptoms mimicking rheumatologic diseases: A single-center retrospective study. Eur J Med Genet. $2021 ; 64: 104185$.

38. Folkestad L, Stochholm K, Groth K, Hove H, Andersen NH, Gravholt CH. Fracture Rates and Fracture Risk in Patients With Marfan Syndrome: A Nationwide Register-Based Cohort Study. J Bone Miner Res Off J Am Soc Bone Miner Res. 2021;36:901-9.

39. Cobben JM, Oostra R-J, van Dijk FS. Pectus excavatum and carinatum. Eur J Med Genet. 2014;57:414-7.

40. Becerra-Muñoz VM, Gómez-Doblas JJ, Porras-Martín C, Such-Martínez M, Crespo-Leiro MG, BarrialesVilla $\mathrm{R}$, et al. The importance of genotype-phenotype correlation in the clinical management of Marfan syndrome. Orphanet J Rare Dis. 2018;13:16.

\section{Figures}
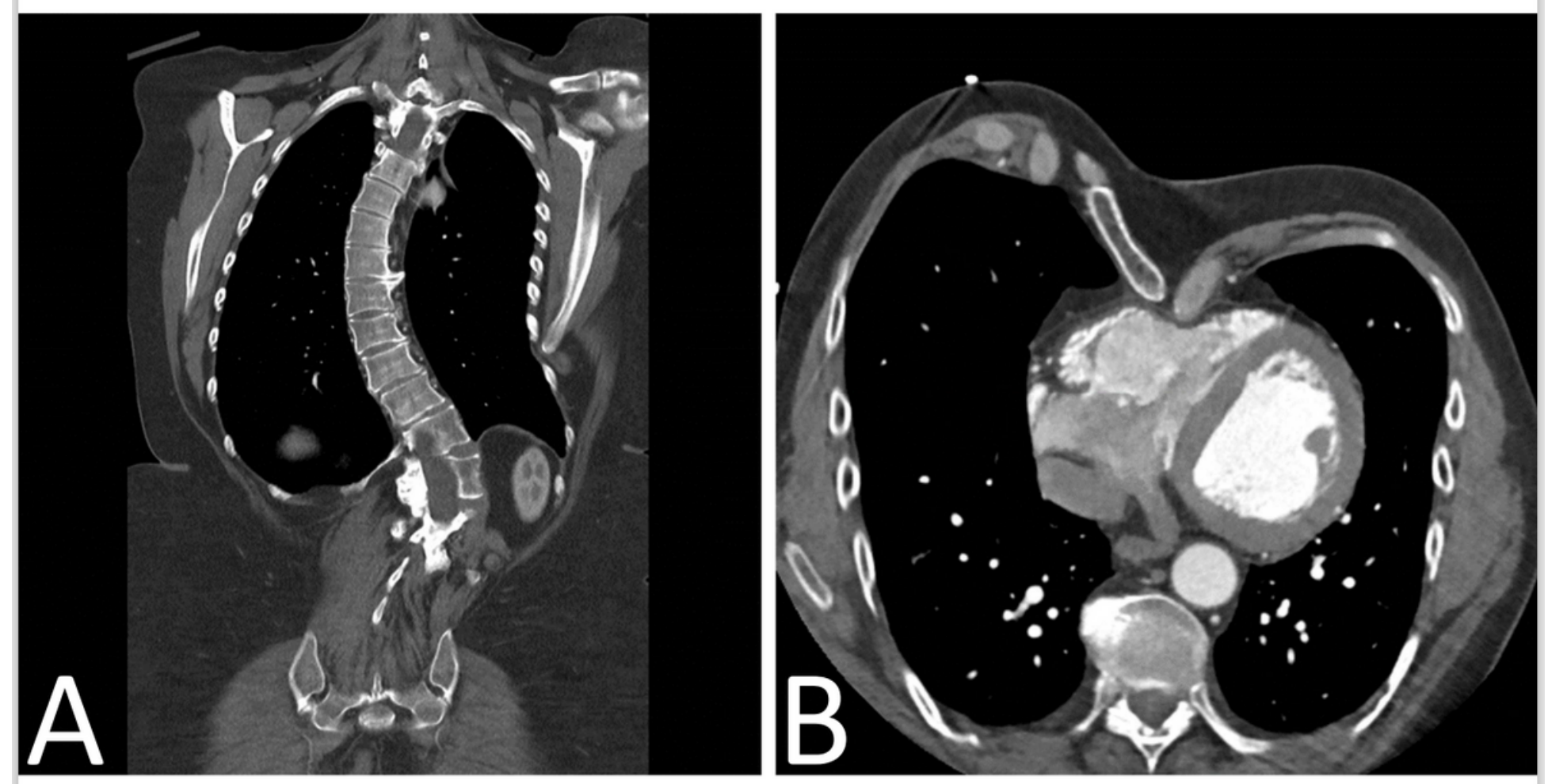

Figure 1 
Skeletal abnormalities in two adults with Marfan syndrome A) 37-year-old women with new diagnosed Marfan syndrome. CT scan reveals a thoracic dextroscoliosis with osteophytes. B) 56-year-old male with severe pectus excavatum and compression of the right ventricle. Even though the patient was diagnosed as a child he was never offered corrective surgery of the chest.

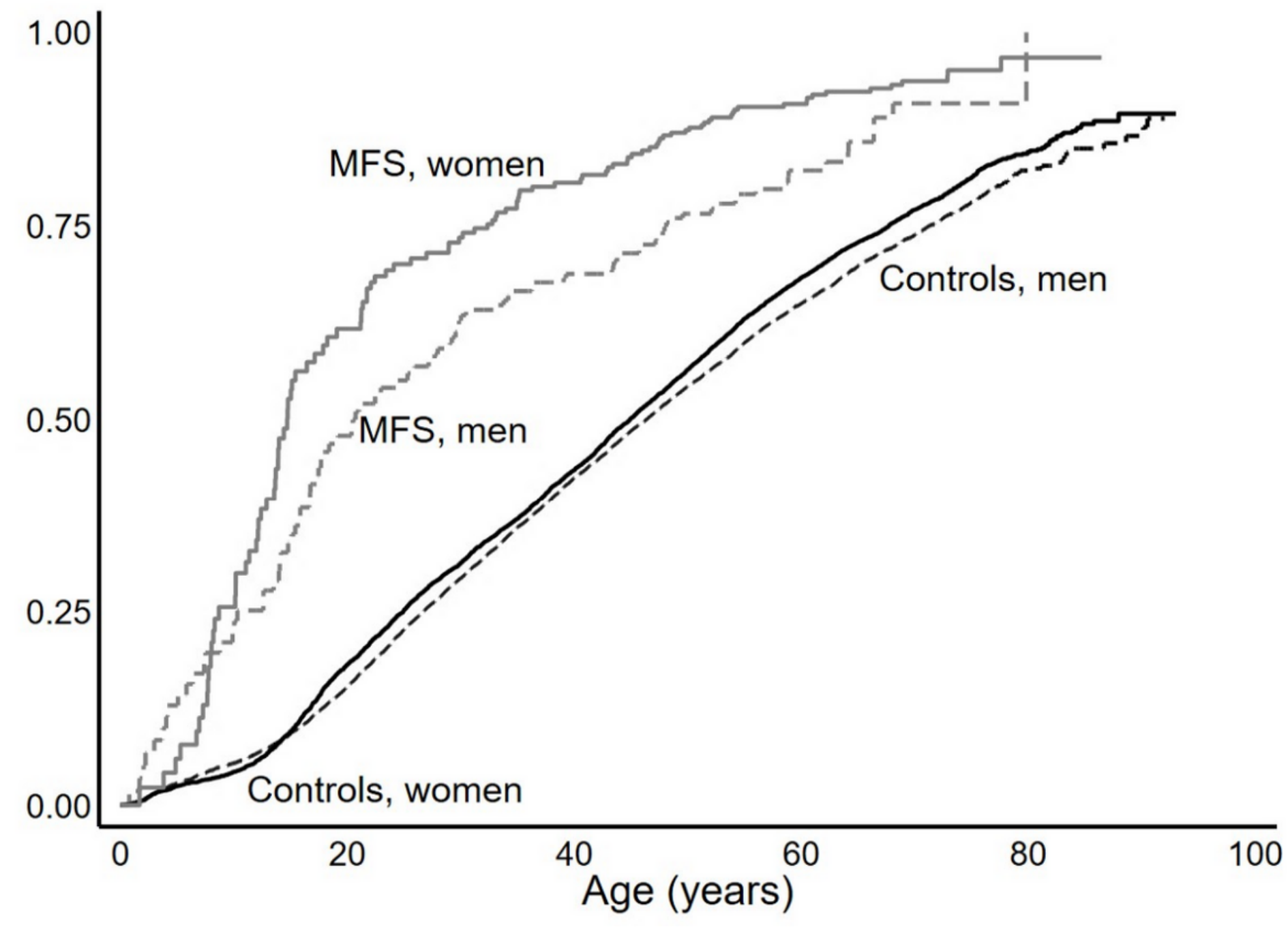

Figure 2

Musculoskeletal diagnoses in Marfan syndrome and the background population Women with Marfan syndrome (solid gray line), men with Marfan syndrome (dashed gray line), control females (solid black line) and males (dashed black line) from the background population registered with of a musculoskeletal diagnosis, corresponding to ICD-10 code DM001 to DM799, for the first time. 


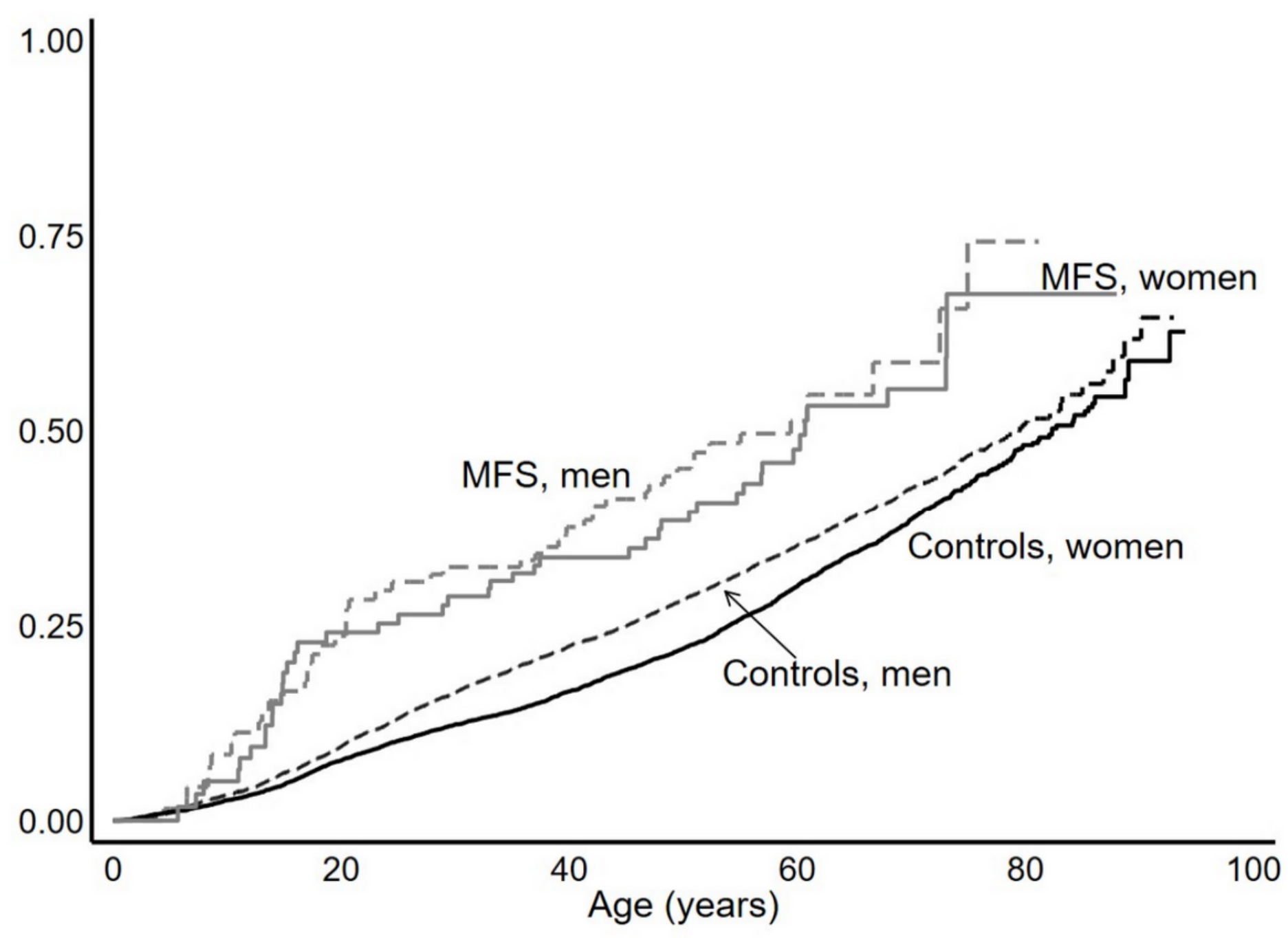

Figure 3

Musculoskeletal surgery in Marfan syndrom Proportion of women with Marfan syndrome (MFS) (solid gray line), men with MFS (dashed gray line), control females (solid black line) and males (dashed black line) from the background population registered with musculoskeletal surgery, corresponding to NOMESCO code KN, for the first time. 